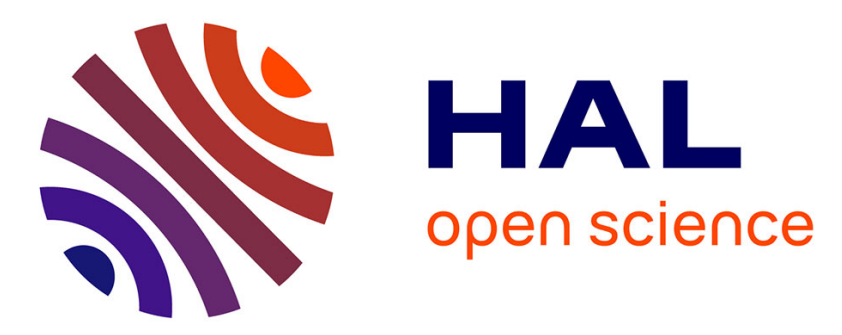

\title{
Die Attach of Power Devices Using Silver Sintering - Bonding Process Optimization and Characterization
}

Cyril Buttay, Amandine Masson, Jianfeng Li, Mark C. Johnson, Mihai Lazar, Christophe Raynaud, Hervé Morel

\section{- To cite this version:}

Cyril Buttay, Amandine Masson, Jianfeng Li, Mark C. Johnson, Mihai Lazar, et al.. Die Attach of Power Devices Using Silver Sintering - Bonding Process Optimization and Characterization. HiTEN 2011, Jul 2011, Oxford, United Kingdom. pp.1-7. hal-00672619

\section{HAL Id: hal-00672619 https://hal.science/hal-00672619}

Submitted on 21 Feb 2012

HAL is a multi-disciplinary open access archive for the deposit and dissemination of scientific research documents, whether they are published or not. The documents may come from teaching and research institutions in France or abroad, or from public or private research centers.
L'archive ouverte pluridisciplinaire HAL, est destinée au dépôt et à la diffusion de documents scientifiques de niveau recherche, publiés ou non, émanant des établissements d'enseignement et de recherche français ou étrangers, des laboratoires publics ou privés. 


\title{
Die Attach of Power Devices Using Silver Sintering - Bonding Process Optimisation and Characterization
}

\author{
Cyril Buttay ${ }^{1}$, Amandine MAsson ${ }^{1}$, Jianfeng LI $^{2}$, Mark JOHnSON ${ }^{2}$, \\ Mihai LAZAR ${ }^{1}$, Christophe RAYNAUD ${ }^{1}$, Hervé MOREL ${ }^{1}$ \\ ${ }^{1}$ Université de Lyon, F-69621, France \\ CNRS, UMR5005, France, \\ INSA Lyon, Université Claude Bernard Lyon 1 \\ Laboratoire Ampère, \\ bâtiment L. de Vinci, 21 avenue Capelle \\ F-69621, France \\ cyril.buttay@insa-lyon.fr \\ ${ }^{2}$ Faculty of Engineering \\ University of Nottingham \\ University Park \\ Nottingham \\ NG7 2RD \\ United Kingdom
}

\begin{abstract}
Silver sintering is becoming an attractive alternative to soldering, especially for high temperature applications. Indeed, the increase in operating temperature requires new soldering alloys with even higher melting points. Silver sintering, on the contrary, is a solution which only require moderate $\left(<300^{\circ} \mathrm{C}\right)$ process temperature.

In this paper, we present the implementation of a die attach technique based on sintering of some silver paste, with a special focus on the practical considerations. A good quality bond can be achieved by paying attention to the assembly process.
\end{abstract}

\section{Keywords}

« Die attach », « silver sintering », « Shear test », « high temperature packaging ».

\section{Introduction}

Soldering is the most common die-attach technique for power electronic devices. Indeed, such components require a bond that is both electrically and thermally conductive. Classical solder alloys include lead-free SACs ( $\mathrm{Sn}, \mathrm{Ag}, \mathrm{Cu}$, with a melting temperature slightly higher than $200^{\circ} \mathrm{C}$ ), HMP (High Melting Point, with a high lead content, around $300^{\circ} \mathrm{C}$ ), and gold-based alloys (Au-Sn, Au-Ge, AuSi, up to $362^{\circ} \mathrm{C}$ ).

High temperature electronics obviously require die attaches that have a high melting point. Furthermore, as a material approaches its melting temperature, its mechanical performances decrease dramatically. Therefore, a safety margin should be kept between the operating temperature and the melting point of the die attach material.

The ratio between the operating and melting temperatures (expressed in kelvin) of a material is called the homologous temperature. For electronics applications, it is commonly as high as 0.8 or more. However, even with such a high value, it can be seen that as the operating temperatures increase, soldering alloys with much higher melting points are required: for $T_{\text {operating }}=$ $200^{\circ} \mathrm{C}(473 \mathrm{~K})$, a melting point of $\frac{473}{0.8}=591 \mathrm{~K}\left(318^{\circ} \mathrm{C}\right)$ is necessary. For $T_{\text {operating }}=300^{\circ} \mathrm{C}$, the solder must remain solid up to $443^{\circ} \mathrm{C}$. This requires a high temperature bonding process, resulting in an increased level of residual stresses.
A survey of high-temperature die attach solutions has been recently published [1]. Among the solutions presented, some are not based on soldering, i.e the bonding process can be performed at a temperature lower than the melting point of the resulting joint. They are attractive, as they present the advantage of a low-temperature process (low level of residual stress) and of the high melting temperature (wide safety margin between operating temperature and melting point, or low homologous temperature value).

The first solution is the Transient Liquid Phase Bonding (TLPB), in which a thin layer of a low-melting point material A (tin, indium...) acts as a liquid phase between two thicker solid layers of material B. As material A diffuses into B, isothermal solidification occurs. Eventually, one ends up with a single phase, with a melting temperature higher than that of material A. Results have been presented using a thin layer of tin between copper layers [2] or between silver layers [3]. In some cases, indium was used instead of tin [4]. Other solutions exist, based on gold-tin, bismuth, ...

Another approach is based on powder sintering. This technique has been studied for the last 20 years [5]. A metal powder is mixed with organic materials (thinner, binder, dispersant) to form a paste. Silver is usually chosen as the metal, because of its excellent thermal and electrical performances [6], its reasonable price and its low temperature sintering capability. Furthermore, sil- 
ver can be sintered in the presence of air. The silver paste is printed or dispensed on a substrate, exactly like a solder paste, and the die is placed on top of the paste. Pressure (several tens of MPa) and temperature (around $240^{\circ} \mathrm{C}$ ) are then applied for the sintering to occur. Such die attach solution is being used for industrial production [7].

The pressure applied during sintering requires specific tooling to avoid breaking the semiconductor dies. To avoid or reduce the need for pressure, it is possible to use silver particles with a smaller size. Indeed, reducing the particles size results in a higher specific surface (more particle surface per powder volume), and makes them more prone to sinter. This can be used either to reduce the sintering temperature (room temperature sintering was demonstrated in [8]) or to reduce the sintering pressure [9]. Zero-pressure sintering has been demonstrated, but it was also found that applying a reasonable amount of pressure (5 MPa) improves the bond quality, especially for the largest dies $\left(1 \mathrm{~cm}^{2}\right)$ [10]

In the present article, we will focus on this nanoparticle silver paste. The objective is to study the bonding parameters, in order to achieve a well controlled (i.e. reproducible) die attach, and to describe the process details.

\section{Die attach procedure}

\subsection{Silver Paste}

The paste selected is the Nano Ag paste from NBE Tech [9], containing additives (binder, dispersant, thinner) and nano Ag particles (8-12 nm size). Several articles have focused on the bonding process using this paste. The main parameters being studied were the temperature profile [11] (number and temperatures of the steps, ramping time...) and the die size [10]. Therefore, the temperature profile used in this study (Fig 1) could be directly selected from the literature.

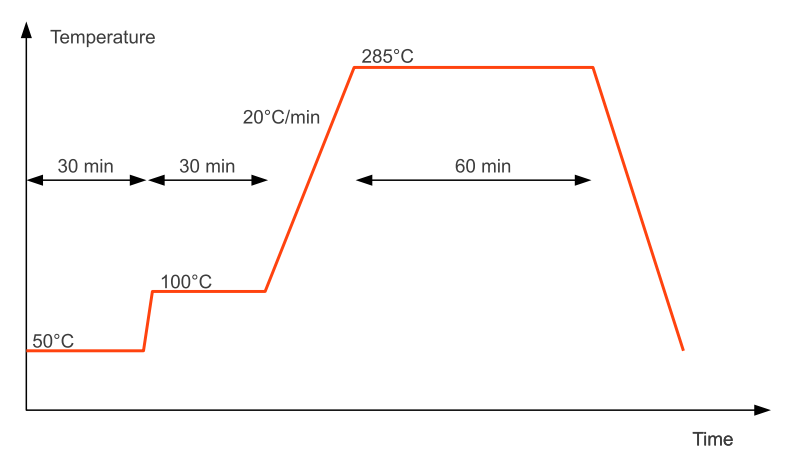

Figure 1: The temperature profile used for the single-step sintering

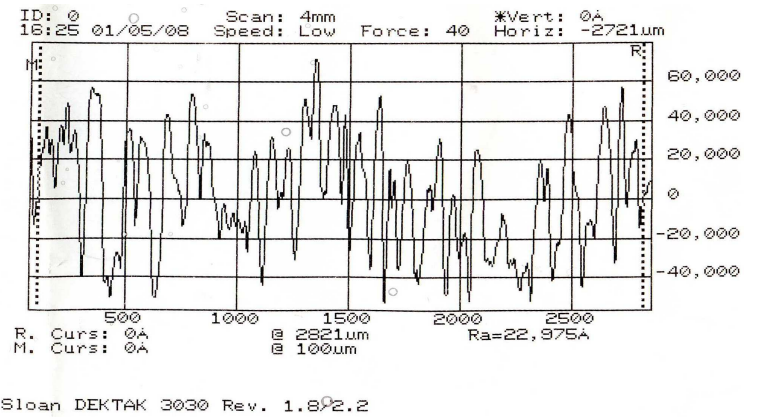

(a)

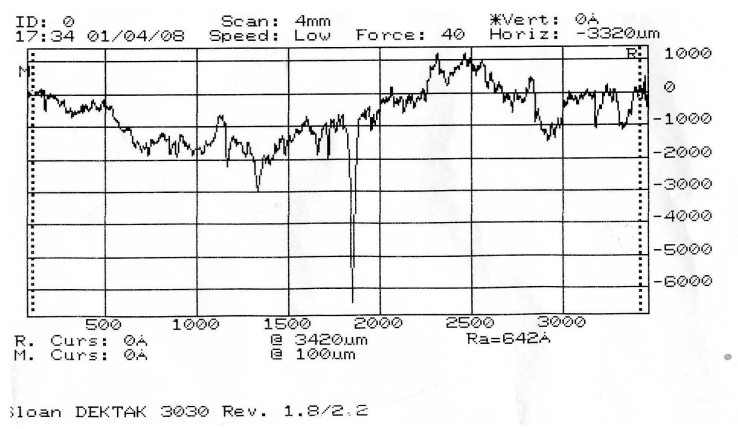

(b)

Figure 2: Surface profile of a DBC as shipped (a), with a surface roughness $\left(R_{a}\right.$, arithmetic average) of $2.298 \mu \mathrm{m}$. After polishing (b) $R_{a}=64.2 \mathrm{~nm}$. The vertical scale of the plots is in angstroms, the horizontal scale is in micrometers.

\subsection{Substrate and die}

The main substrate used for this study is Direct Bonded Copper (DBC) from Curamik $\left(635 \mu \mathrm{m}\right.$ of $\mathrm{Al}_{2} \mathrm{O}_{3}$ with $300 \mu m$ of copper clad on both sides). For some tests, one of the copper surface was polished in order to reduce the surface roughness (see Fig 2). In both cases, the copper surface was cleaned immediately before the assembly: 5 minutes dip in $\mathrm{H}_{2} \mathrm{SO}_{4}(96 \%)$ to remove oxidation, followed by rinsing in deionized water, and 3 minutes in ethanol (US bath). The samples were then dried using a nitrogen blow nozzle.

For two series, other substrates were used: one series was made using a Curamik DBC with a nickel-gold fin-

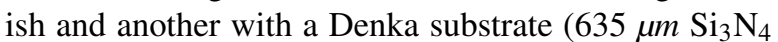
with $300 \mu m$ copper), also with a nickel-gold finish. Although the gold layer provides protection against oxidation, the cleaning process was kept identical $\left(\mathrm{H}_{2} \mathrm{SO}_{4}\right.$, rinsing, ethanol, drying).

The SiC dies are mechanical samples ("dummy chips") provided by SiCED. They measure $2.7 \times$ $2.7 \mathrm{~mm}$, with a silver backside finish. Prior to assembly, they were cleaned as follows: 3 minutes in ethanol (US bath), followed by drying using a nitrogen blow nozzle.

\subsection{Application of the Paste}

The silver paste can was first opened in april 2009, and has since been stored at room temperature. Although it 


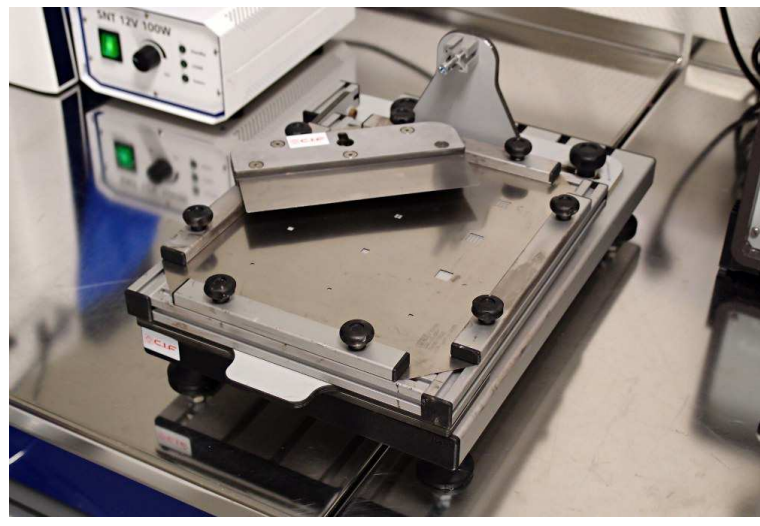

Figure 3: The manual screen-printing system, with its stainless-steel squeegee. The screen size is roughly equivalent to the A4 paper format

is supposed to have a pot life of one year only, no change in consistency or in sintering behaviour was noticed. It was therefore decided to pursue the tests with the same paste, even once it has passed its expiry date.

The paste was applied by screen printing, to ensure a uniform deposit thickness. Two stencils were used: $50 \mu \mathrm{m}$ and $100 \mu \mathrm{m}$. While paste manufacturers advise to use the thinner, it is much more expensive (around $500 €$ ) than the thicker (around $150 €$ ). This is because thin screens are obtained by electroforming (similar to electroplating), while screens of $100 \mu \mathrm{m}$ and thicker are laser cut in a metal foil.

The screens were attached to a simple frame, with a manual squeegee (fig. 3). The paste has a thick consistency, making it relatively easy to print, with a good shape retention. However, if it is simple to print, the paste is very difficult to clean. Extra care should be taken not to stain any surface with the paste. Nickel or stainless steel screens can be cleaned without too much trouble (using isopropyl alcohol or ethanol), but this is not the case with more porous surfaces such as anodized aluminium. In many cases, cleaning attempts simply results in the spreading of the paste! Furthermore, as the effect of silver nanoparticles on living cells is still investigated [12], it is important to wear gloves when handling stained equipments.

\subsection{Sintering}

As described in section 1 , the main objective of using nano-particles of silver is to reduce the pressure required to less than a few mega-pascals. Most presses are designed to apply forces upwards of a kilo-newton, and the silicon carbide dies tend to be small (in our case $2.7 \times 2.7 \mathrm{~mm}$ ). This results in pressures exceeding $100 \mathrm{MPa}$. Therefore, a specific press was developed for our application. A photo can be seen in fig. 4 and the mechanical structure is described in fig. 5 .

This press can apply forces ranging from $5 \mathrm{~N}$ to approximately $1 \mathrm{kN}$. This latter value is require to attach several dies at the same time. Both heating platens can

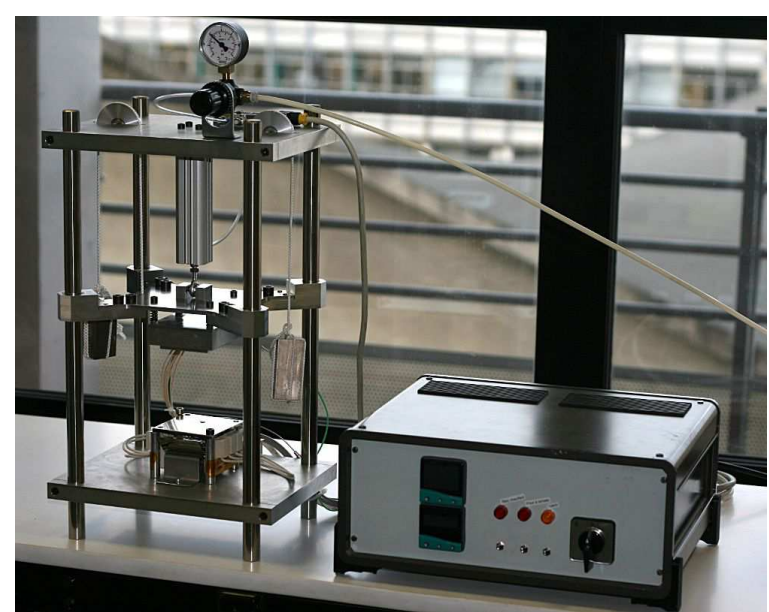

Figure 4: This sintering press (specific developpement) is equiped with two heating platens (heating rate exceeding $50^{\circ} \mathrm{C}$ per minute) and can apply forces ranging from a few newtons up to several hundred newtons.

be controlled synchronously or independently, and the pressure can be applied or removed at any time during the bonding cycle. Both platens can achieve $50^{\circ} \mathrm{C} / \mathrm{min}$ ramping time and are equipped with $750 \mathrm{~W}$ heating power (cartridge heaters for the top platen, lamps for the bottom platen). A force sensor has recently been installed (not visible in fig. 4, but represented in fig. 5) to measure the actual force applied by the press. This force can be adjusted by changing the air pressure in the pneumatic cylinder.

The parallelism between both platens is ensured by a moving frame which slides (using ball bearings) along four shafts. The top platen is secured to this moving frame via 4 springs in order to accommodate a possible tilt of the die. To bond several dies simultaneously, or if the die is fragile (large and thin) a soft material (viton ${ }^{\mathrm{TM}}$ rubber or PTFE) is placed between the dies and the top platen. On the contrary, to bond a single, small die, no interface material is used, the die is in direct contact with the top aluminium platen.

After paste printing, the substrate is put in the press (fig. 4). The die is then carefully placed on top of the paste deposit. No force is applied on the die at this stage. The press is then turned on.

For most of the assemblies described in this paper, the pneumatic cylinder (see fig. 5) is actuated from the beginning of the cycle in fig. 1. This ensures a good contact between the die and the fresh paste.

For some assemblies, however, a two-step printing of the paste was used. This method is described in [10]: the paste is printed on the substrate, and dried at $150^{\circ} \mathrm{C}$ without any pressure to remove the organic materials. Then a fresh lump of paste is printed, using the same screen, and the die is placed on top of the deposit. The rest of the process is identical to the one-step technique (temperature profile of fig. 1). This technique is supposed to give better results with large dies. 
Table 1: Test matrix for the $\mathrm{SiC}$ dies

\begin{tabular}{c|c|c|c|l} 
Series & thickness & substrate & bonding pressure & remarks \\
\hline $\mathrm{A}^{\prime}$ & $50 \mu \mathrm{m}$ & Raw DBC & $6 \mathrm{MPa}$ & \\
$\mathrm{B}$ & $50 \mu \mathrm{m}$ & Raw DBC & $6 \mathrm{MPa}$ & manual scrubbing to get good die-paste contact \\
$\mathrm{C}$ & $50 \mu \mathrm{m}$ & Au-finished DBC & $6 \mathrm{MPa}$ & \\
$\mathrm{D}$ & $50 \mu \mathrm{m}$ & Au-finished $\mathrm{Si}_{3} \mathrm{~N}_{4}$ & $6 \mathrm{MPa}$ & \\
$\mathrm{E}$ & $50 \mu \mathrm{m}$ & polished DBC & $6 \mathrm{MPa}$ & \\
$\mathrm{F}$ & $100 \mu \mathrm{m}$ & Raw DBC & $6 \mathrm{MPa}$ & \\
$\mathrm{J}$ & $50 \mu \mathrm{m}$ & Raw DBC & $0.7 \mathrm{MPa}$ & \\
$\mathrm{N}$ & $50+50 \mu \mathrm{m}$ & polished DBC & $6 \mathrm{MPa}$ & two-step screen printing \\
$\mathrm{O}$ & $50+50 \mu \mathrm{m}$ & Raw DBC & $6 \mathrm{MPa}$ & two-step screen printing \\
\hline
\end{tabular}

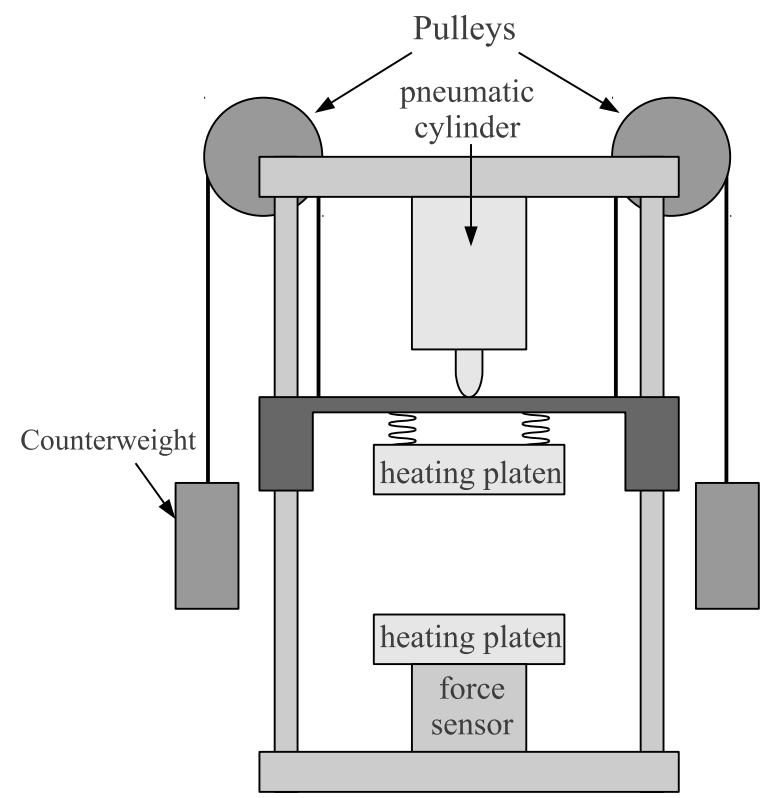

Figure 5: mechanical structure of the press. The mobile frame is attached to two counterweights, to achieve a low minimal force $(<5 \mathrm{~N})$.

\section{Effects of the process parame- ters}

A first series of experiments is listed in table 1. For each series, at least 6 die attaches were performed: 1 was kept for micro-section and microscope inspection, while the remaining assemblies were used for mechanical (destructive) testing. The objective was to find the parameters that would not only result in a strong bond, but more importantly that would result in a reproducible bond. That is, to find the parameters for which all dies attaches would break for the same force applied.

Due to the shape of the assemblies, the most practical (and commonly used) bond strength assessment is the so-called "shear test" in which a tool applies a horizontal force on one side of the die, the substrate being kept secured. This results in a shear stress in the die attach. The shear strength is the maximum force recorded before the failure of the die attach divided by the die surface area. The test equipment used is visible in fig. 6 .

The results are visible in figure 7 . It can be seen that

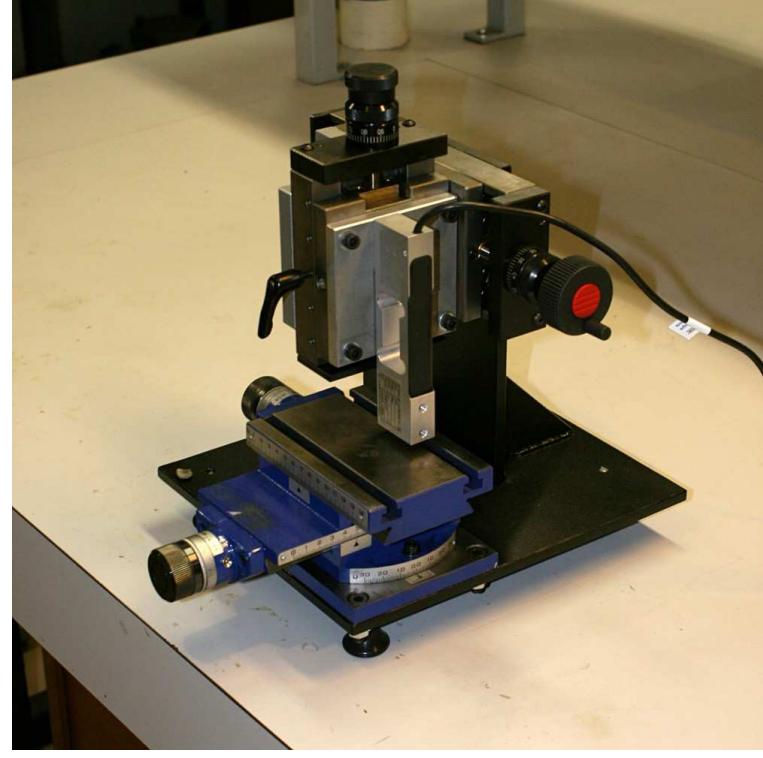

Figure 6: The shear tester used (specific development), with a $20 \mathrm{kgf}(200 \mathrm{~N})$ load cell mounted

for most series, the results are spread over a wide range. Only series E show an acceptable level of reproducibility.

Two mechanisms can explain the poor reproducibility of all series except series E:

- The roughness of the substrate: as can be seen in figure 8 (as well as in figure 2), the roughness of a "raw" DBC is comparable with the thickness of the silver joint. This means that on some places, the die can be in direct contact with the DBC, while on other, the silver layer is not thick enough to prevent voiding. On a polished DBC, on the opposite, the silver joint is of regular thickness. This could explain the spreading of series A', B, C, D, F, J

- The oxidation of the copper layer: for the two-step deposits (series $\mathrm{N}$ and $\mathrm{O}$ ), the copper under the silver deposit has more time to oxidize, resulting in a weaker silver-to-copper bond.

As a result, the most satisfying parameter set was found to be: $50 \mu \mathrm{m}$ of silver paste on a polished substrate, with $6 \mathrm{MPa}$ pressure applied on the die. 


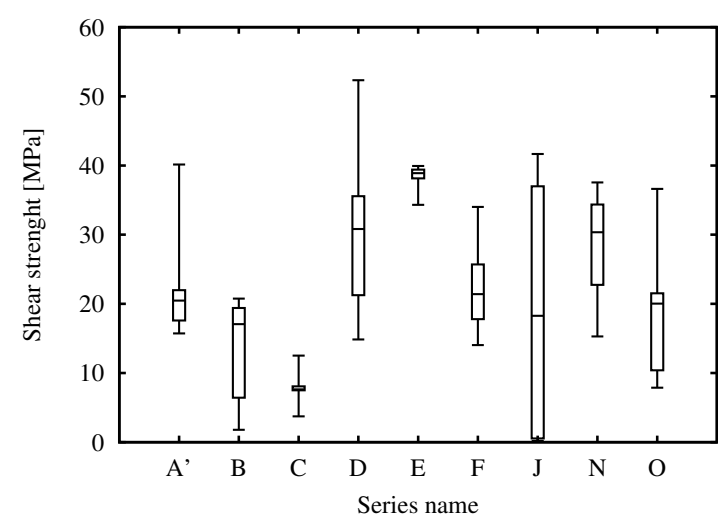

Figure 7: Shear strength measured for the series described in table 1 . The line in each box corresponds to the median value ( $2^{\text {nd }}$ quartile), and the lower and upper limits of the box represent the first and third quartile respectively. The "whiskers" correspond to the extreme values. In other words, $50 \%$ of the samples are in the box, $25 \%$ in the lower whisker and $25 \%$ in the top whisker.

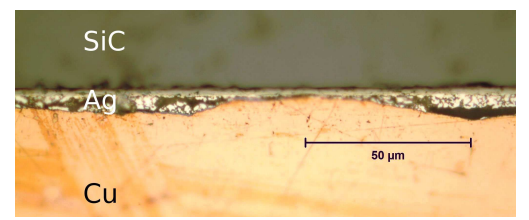

(a)

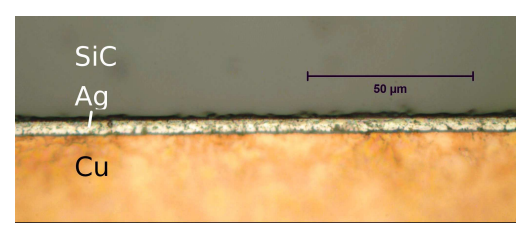

(b)

Figure 8: cross section of a sample of series A' (raw DBC, (a)) and of series E (polished DBC, (b)). It can be seen that the roughness of the raw $\mathrm{DBC}$ is comparable to the silver joint thickness.

Note that the silver layer thickness after sintering was found to be under $10 \mu \mathrm{m}$, which is much less than expected (around half the thickness of the fresh paste, or $25 \mu \mathrm{m})$. This is because a large part of the paste is "squeezed" out when applying the pressure. In series $\mathrm{F}$, a thicker screen was used to deposit $100 \mu \mathrm{m}$ of paste, but no improvement was observed. The pressure was reduced for series $\mathrm{J}$, but that resulted in an even less predictable result. In series $\mathrm{N}$ and $\mathrm{O}$, the two-stage deposit (also aimed at producing a thicker silver layer) did not show any improvement over series A'.Finally, series B, in which a manual scrubbing was performed on the dies to improve their contact with the silver paste, show a very poor adhesion. This can be explained by the scrubbing motion, which tends to further reduce the silver layer thickness. As the failure mechanism for all the assemblies was a fracture along the silver-substrate interface, improving the die-silver interface did not bring any improvement.

For all assemblies performed on bare copper substrates, it was found that the exposed copper surfaces were deeply oxidized. This means that a gold-finish is desirable (silver sintering was found not to adhere directly on nickel). The substrates used for series D only have a gold-flash finish $(50 \mathrm{~nm})$ on a nickel plate, but this thin gold layer was found to be sufficient to record the best shear strength $(52.3 \mathrm{MPa})$.

\section{Other experimental considera- tions}

\subsection{Simultaneous bonds}

With the chosen temperature profile, which is fairly slow compared to soldering (almost 3 hours including cooling-down), it is important to bond several dies at once. As the silver layer is very thin, it does not allow to accommodate any difference in height between dies, or any irregularity in substrate thickness.

Therefore, an interface material is necessary between the dies and the top platen or the press. Two materials were assessed: PTFE and Viton. Both are $1.5 \mathrm{~mm}$ thick. PTFE is more rigid, while Viton has a rubber-like consistency.

With both materials, a satisfying bond could be achieved. However, the dies left a deep imprint in both interface materials. Also, the silver paste "squeezed out" from under the die stuck on the interface material, meaning that it could not be reused without polluting the top of the following dies with silver. This is an issue, as both materials are relatively expensive.

\subsection{Large dies}

$9 \times 9 \mathrm{~mm}$ and $12.7 \times 12.7 \mathrm{~mm}$ silicon dies were used to evaluate the practical aspects of bonding large dies. As with the smaller SiC dies, the first attempts were conducted with a fairly stiff interface material between the dies and the top platen (a graphite foil).

As it can be seen in figure 9, this resulted in the bowing of the die: the silver layer is found to be much thinner at the edges of the die than in the middle. This is because the top of the die is not flat: the edge passivation (several tens of microns thick) protrudes from the die and makes contact with the platen, while the top metallization is in a recess and does not touch the platen. Therefore, even for a single die, a soft interface material is required for large dies to approach quasi-isostatic conditions.

The image of one of the silver layers is visible in figure 10. This image shows that what appears to be a solid layer of silver with the optical microscope actually consists of 200 to $1000 \mathrm{~nm} \mathrm{Ag}$ grains with 150 to $400 \mathrm{~nm}$ pores/voids. 


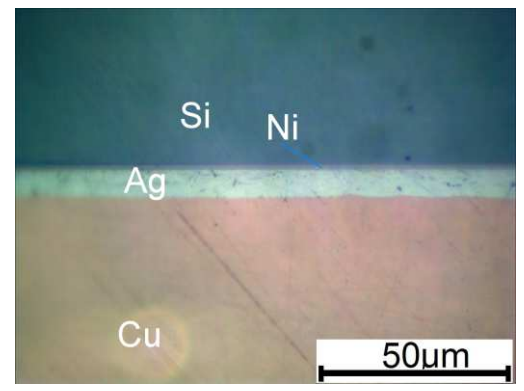

(a)

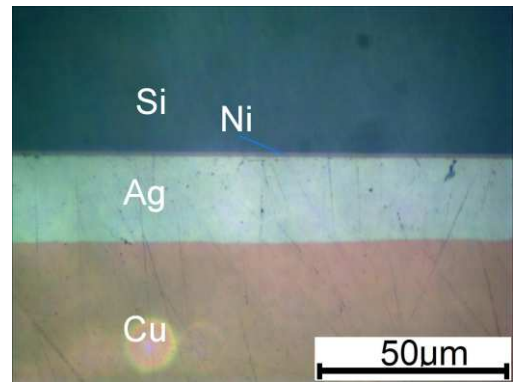

(b)

Figure 9: cross section of the die attach of a $9 \mathrm{~mm} \mathrm{Si}$ die at the edge (a) and in the middle (b).

\section{Conclusion}

The implementation of a silver-sintering based solution for die attach has been described. Although this technology does not require very complex equipments (the process takes place in air, with moderate temperature and pressure), some precautions must be taken to ensure good results.

In particular, it was shown that the roughness of the substrate has a very significant effect on the reproducibility of the die attach. Other effects, such as substrate finish or the thickness of the paste deposit, are not as obvious. In particular, further experiments are needed to reduce the pressure required and achieve thicker silver joints.

\section{Acknowledgments}

The authors would like to thank the "Fondation pour la Recherche en Aéronautique et Espace" (FRAE) its financial support of this work, under grant name "EPAHT"

\section{References}

[1] V. Manikam and K. Y. Cheong, "Die Attach Materials for High Temperature Applications: A Review," Components, Packaging and Manufacturing Technology, IEEE Transactions on, vol. 1, no. 4, pp. 457 -478, april 2011.

[2] K. Guth, D. Siepe, J. Görlich, H. Torwesten, R. Roth, F. Hille, and F. Umbach, "New assembly and inter-

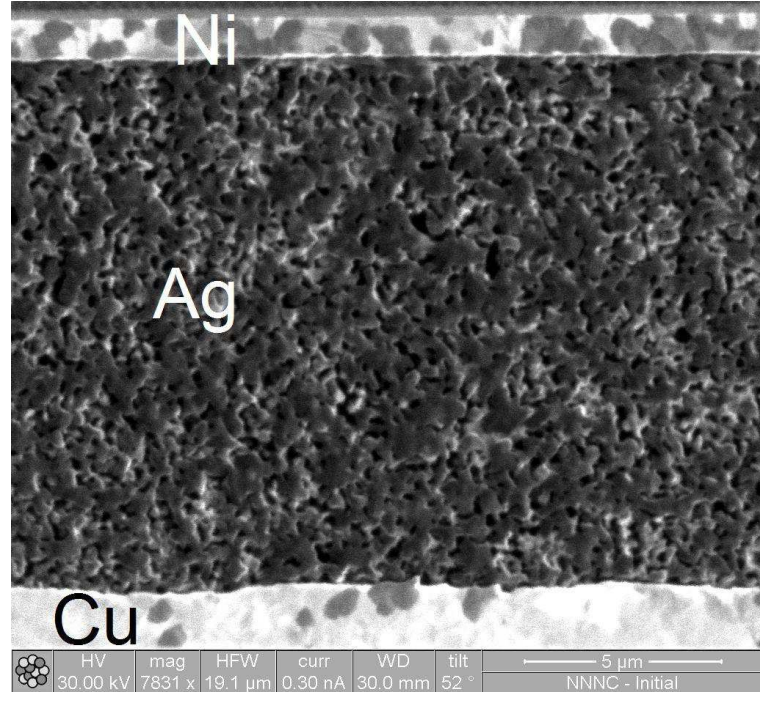

Figure 10: FIB ion channelling contrast image of a silver joint between a Si die and an DBC substrate (FIB micro-section)

connects beyond sintering methods," in Proceedings of PCIM, Nuremberg, may 2010, pp. 232-237.

[3] B. McPherson, J. M. Hornberger, J. Bourne, A. B. Lostetter, R. M. Schupbach, R. Shaw, B. Reese, B. Rowden, H. A. Mantooth, S. Ang, J. C. Balda, K. Okumura, and T. Otsuka, "Packaging of High Temperature 50kW SiC Motor Drive Module for Hybrid-Electric Vehicles," Advancing Microelectronics, vol. 37, no. 1, pp. 20-26, jan 2010.

[4] P. O. Quintero, T. Oberc, and F. P. McCluskey, "High Temperature Die Attach by Transient Liquid Phase Sintering," in HiTEC 2008. Albuquerque: IMAPS, may 2008, pp. 207-212.

[5] H. Schwarzbauer, "Method of securing electronic components to a substrate." U.S Patent Patent 4810672 , mar 7, 1989. [Online]. Available: http://www.google. $\mathrm{com} /$ patents/about $? \mathrm{id}=\mathrm{ViVhAAAAEBAJ} \& \mathrm{dq}=4810672$

[6] H. Schwarzbauer and R. Kuhnert, "Novel large area joining technique for improved power device performance," Industry Applications, IEEE Transactions on, vol. 27, no. 1, pp. 93 -95, jan. 1991.

[7] C. Göbl, P. Beckedahl, and H. Braml, "Low temperature sinter technology Die attachment for automotive power electronic applications," in Automotive Power Electronics, Paris, 21-22 jun 2006, p. 5. [Online]. Available: www.semikron.com/internet/webcms/objects/pdf/ APE2006_Goebl.pdf

[8] D. Wakuda, K.-S. Kim, and K. Suganuma, "Ag Nanoparticle Paste Synthesis for Room Temperature Bonding," IEEE Transaction on Components and Packaging Technology, vol. 33, no. 1, pp. 1-6, mar 2010.

[9] G. Bai, "Low-Temperature Sintering of Nanoscale Silver Paste for Semiconductor Device Interconnection," Ph.D. dissertation, Virginia Polytechnic Institute and State University, Blacksburg, Virginia, oct 2005. [Online]. Available: http://scholar.lib.vt.edu/ theses/available/etd-10312005-163634/unrestricted/ Dissertation-GBai05.pdf 
[10] T. G. Lei, J. N. Calata, G.-Q. Lu, X. Chen, and S. Luo, "Low-Temperature Sintering of Nanoscale Silver Paste for Attaching Large-Area $\left(>100 \mathrm{~mm}^{2}\right)$ Chips," IEEE Transaction on Components and Packaging Technology, vol. 33, no. 1, pp. 98-104, mar 2010.

[11] T. Wang, X. Chen, G.-Q. Lu, and G.-Y. Lei, "LowTemperature Sintering with Nano-Silver Paste in DieAttached Interconnection," journal of electronic materials, vol. 36, no. 10, pp. 1333-1340, 2007.

[12] N. Lubick, "Nanosilver toxicity: ions, nanoparticles or both?" Environmental Science \& Technology, vol. 42, no. 23, pp. 8617-8617, 2008. [Online]. Available: http://pubs.acs.org/doi/abs/10.1021/es8026314 